\title{
PROBLEMS OF TOURISM DEVELOPMENT IN THE REPUBLIC OF SERBIA
}

\author{
Milutin Matković \\ Faculty of Applied Management, Economics and Finance, Belgrade, Serbia \\ (c) MESTE NGO \\ JEL Classification: C1, M4, Y90
}

\begin{abstract}
Tourism represents one of few real chances for significant development that Serbia have. Serbia is rich in natural and cultural resources. Great variety of tourism resources concentrated in Serbia provides many possibilities for tourism development. In order for tourism to become one of the main strongholds of Serbian economy, there must be a strategy that will give guidelines for its future development. There are several main problems of Serbian tourism. Biggest one is the lack of traffic infrastructure. Also, Serbia is not very well recognized as attractive tourist destination. Tourist facilities are insufficiently developed. Also, the structure of employees working in the field of tourism industry in Serbia is problematic. The fact that tourists stay in Serbia between three and five days, means that tourists are not very well informed about the possibilities that Serbian tourism offers. Making Serbia globally recognizable as an attractive tourist destination is a task reachable only whit the synergetic effect of all relevant factors in this process.
\end{abstract}

Keywwords: Tourism, development, problems of segmentation, resources, solutions, advantages

\section{INTRODUCTION}

Tourism is targeted as one of the key instruments of Serbia's economic development in the near future. Richness and diversity of its natural and cultural resources, give Serbia possibility to become recognizable tourist country. To make it possible Serbia must have strategy that will guide its way to tourist map of the world. Problems that Serbia has to face during this proces are many, like recent political history, problems related whit tourist infrastructure, profiles of employees in tourism, lack of recognition among tourists, as well as deficiency of tourist demand.

Address of the corresponding author:

Milutin Matković

㭋='milutin.matkovic@gmail.com
Whitout state strategy that will cover every aspect of tourism development, it will be impossible to obtain the level needed for establishing Serbia as respectable tourist destination.

\section{TOURISM IN SERBIA}

Tourism has a potential to become one of the most profitable industries in the country. But, Serbia is very fragmented as a tourist destination (Popesku, 2011.). To obtain that goal, tourism potential must be recognized by state not only as possible solutions and future plans, but also trough concrete steps that will help achieve that goal. This is necessary because without help from the state, there is so little that a single organization or expert could do. In other words without state help it will all remain in area of possible dreams. 
It seems like Serbia stood aside, while the tourist market was developing, adjusting tourist product for more specific target markets (Bakić, 2005.), Serbia is still struggling with segmentation of its tourist offer. To be more precise, it hasn't done much in this area in last twenty years. It seem like there isn't enough will for this matter among tourist experts in Serbia. If we know that strategy for tourism development is still in primary steps, and plans are still to be written, it is no surprise that specific steps such as segmentation is yet to be achieved. It will be difficult for Serbia to reach a certain level of touristic demand increase without this step, so this may be the critical step in making Serbia well recognized tourist country.

Serbia isn't compatible with concept of modern tourism, and it is necessary to make new strategic planning through team work of all factors (Ceranić, 2003.), relevant for development of tourism in Serbia. Main problem for strategy planning is absence of clear vision what is tourism for Serbia and what are the main goals that should be achieved. If vision is clear and strategy gives firm guidelines for development of tourism, it will be easier to make plans for positioning tourist offer of Serbia on global tourist market. To achieve this vision, it is important to realistically perceive what is Serbia current position in the world, what do people of other countries know and think of Serbia, was it recognized as a tourism destination in the past, what are the advantages that Serbia have and can use in her benefit, is there something unique in tourism offer that Serbia can offer to the customers. Also, it must be determined what is tourism position in Serbia development plans, what are expected benefits of tourism expanding, and how big growth is expected in touristic demand for Serbia in near future. If the vision is determined correctly, next step will be to make clear and reachable goals, that will help in realizing what is needed to be done so Serbia can become wanted tourism destination. If previous steps are done correctly, than plans for putting Serbia on global tourist market can be done whit precise steps and obtainable goals that can be achieved.

Market segmentation reveals target markets and provides right way for full-filling market demands (Živković, 2007.). What differentiate one destination from another are both natural beauty and the number of historical events that happened in the region (Biederman, 2008.), so we can say that Serbia is on right path to become recognized tourist destination, during the fact that there are more than 1300 protected natural objects (Štetić \& Šimičević, 2008.) and numbering all the historical events from past and present that took place in this part of the world. On the other hand, this is only the first step, because every successful destination is a product of integral planning that represents an integrated area which contains accommodation, attractions, local community involvement and transportation (Y. Gee and oth., 1997.). Serbia can use the knowledge that countries in this part of the world have in tourism development to upgrade her own, but it must be aware that every destination has its own advantages and shortcomings, and there is no comprehensive solution for every destination (Lopez-Guzman, Sanches-Canizares \& Pavon, 2011). Tourist market is constantly reshaping fallowing the demand of ever growing tourist population, so future destinations will emphasize value and visitor experience, rather than the volume (Cooper, Fletcher, Fyall, Gilbert \& Wanhill, 2008). If all that is known than it is understood that Serbian tourist market is still to be segmented in a way that modern tourism market demands.

\section{SEGMENTATION OF SERBIAN TOURISM}

Market segmentation enables to determine target market or markets through separation of the market in different groups of tourists, based on their demand (Živković, 2005.). Because of lack of tourism development in last couple of decades, market segmentation of Serbian tourist offer in on the very beginning. There are parts that believe that chance lies in rural development, because rural tourism helps diversification of rural economics (Zrilić, 2011.), others on the other hand think that chance lies in archeological discoveries, Lepenski vir is regular in offer of tour operators from Germany, Holland and Austria, as of 2009 year (Matijašević, 2009.), while government institutions see chance in developing river tourism, so "Were Danube meets Balkans" promo was realized in year 2006 (Službeni glasnik Republike Srbije, 2006.). This variety of guidelines suggests lack of coordination of parts involved in diversification of tourism offering in Serbia. In order to achieve proper segmentation every part 
of Serbia tourism offer must be taken into consideration, and only then can one have clear picture what are strengths and weaknesses and what should be done in order to make Serbia tourism offer not only well segmented, but also organized in a way that should give her a possibility of firm tourism growth. Some of the following segments should be taken into consideration when tourism segmentation in Serbia is in order. There are numerous historical monuments, natural heritage sites, national parks, spas, ethno villages, medieval castles, musical and traditional manifestations, that all make part of tourism offer that Serbia can provide today.

City break is probably the most popular segment among foreign tourists, which usually discover Serbia trough city break in Belgrade. This is because Belgrade is well connected whit the world trough airport, rivers, rail stations and highways. Being a regional center and a multimillion city it has much to offer to tourists of various social and financial background. Belgrade, with his cultural, historical and natural variety, along with his nightlife can be interesting for many. Belgrade can provide sites and events for different tourist groups. There are castles, fortresses, music events, restaurants, clubs, sport events..., also there are picnic spots all located near Belgrade that can also be includes in tourist offer. Skadarlija whit its restaurants and historical background is popular among tourists. Night clubs located on rivers are unique in Europe, and are growing ever popular among foreign tourists. These are all initial points from where the Belgrade tourist offer can be rebuilt. On the other hand, Novi Sad can provide a different holiday all together. Tourist can go on a long walks, pick up between many restaurants, visit museums, galleries, go on a picnic in near villages or visit chardas, restaurants on water with live music. Other towns in Serbia can also be included in city break offer, but their offer is yet to be compound.

Gastronomy tours, if thought out correctly, can be very popular, and also can be divided on several smaller tours. More situated tourists like to discover new tastes on every journey. It can be divided based on regional or food principle. Tour try cuisine in Vojvodina brings tourist great fish and poultry meals, old fashioned sweets and game meats. South region of Serbia is famous by grilled meat and pepper specialties, but it also has vegetarian dishes. Region of central Serbia is well known by skewer meat, such as beef, lamb and pork. Mountain cuisine brings meat delicatessen, milk products, dried fruit, mushrooms... Serbia has long tradition is beverage manufacturing, especially alcoholic drinks. Fruit brandies are made from almost every fruit, and among them plum brandy called sljivovica is most famous one. Rakija tours providing insight in production of brandy, combined with picnic trips and product tasting can be interesting for tourists. Wine tours are very popular today, and Serbia has enough to offer. There are several authentic white and red wines worthy of taste. Wineyards od Fruška Gora offers wine tasting combined whit good food that can be combined with site-seeing and river boat rides. In Eastern Serbia visit to the wine cellars called pimnice can be made. There are also several parishes in central region of Serbia that can be combined for another wine tour. Beside wine and brandy, there are also some other beverage that can be popular such as medovina, drink made of honey.

Musical tours, whit such brands like Guča and Exit and their ever growing popularity, can be one of the most popular segment. Exit and Guča can be used for popularization of other music events in Serbia. Exit is a multistage modern music festival that is very popular among young people, and it can be used for popularization of Serbia tourist offer, as well as Guča, festival of world and ethno music that is growing more and more popular among foreign tourists. Events such as jazz festivals in Belgrade, Niš, festivals of traditional instruments among others can grow popular if advertised correctly.

Archeological tours, whit site-seeing and numerous artifacts, from prehistoric to late 20 century, are yet to be fully discovered from tourists. Serbia is one of few states in the world on whose territory tourist can follow track of human civilization from prehistory to the modern age. Lepenski vir, Vinča, Starčevo, Hisar are among oldest sites whit traces of beginnings of modern man civilization. Then there are artifacts from greek and roman period, particulary numerous from late roman empire period, with several residential sites. There are several dozen medieval fortresses around Serbia that can be used for tourist needs. Places, that famous battles took place at, are popular among visitors, so there 
is yet another niche that can be used. Whit interesting programs attached whit this sites it will be possible to increase interest for archeological sites in Serbia.

MICE tourism can represent advantage of Serbian tourism, if designed correctly. This niche of tourism represents events where top class experts from their expertise summit in order to accomplish new standards. It would be in Serbia benefit to organize such an event. It would be even better to find something, that Serbia has or can improve whit her knowhow, that can be topic of such an event.

Educational tourism can also be significant part of Serbian offer, dye to the fact that some of the best scientist work on Belgrade university. What this means is that Serbia must increase number of summer camps, level of student exchange, number and level of top class universities that Belgrade university has cooperation whit. Students are among first to discover new destinations.

Medical tourism is a hidden chance, but to make it possible Serbian medical infrastructure must be up-graded. Price of medical service is significantly lower than in other states, so it can be Serbia advantage.

River cruises on Danube, Sava, Morava and Drina are only some of the possibilities that Serbian rivers provide to the tourists. Danube is navigable through its entire flow in Serbia which opens many opportunities for tourist development. River goes through two capital cities, and can be used for cruise tours or picnic trips. Several main tourist plans were made for use of Danube, but it hasn't made expected outcome yet. One of the most famous European tracks for F1 Powerboat is on estuary of Sava in Danube. River Sava is also navigable in Serbia. On its river banks are ponds, natural heritage sites, both sport and commercial fishing. Drina is famous by its rafting that endures trough spring and summer of every year. Natural phenomena, settled beaches, traditional manifestations, natural heritage sites, walking tours, monuments from the past are some of the features that rivers in Serbia have, that are waiting to be included in tourist offer.

Spa tours must be among top offers in Serbian tourism, for diversity of their natural springs, long tradition, and possibilities of touring that environment of Serbian spa provides. Spa tradition in this part of the world spreads back to roman times. Some of spas have several centuries long uninterrupted tradition. There are centers for diversity of medical issues, but also places of rest and fun. Vrnjačka and Niška spas are famous for night life, other, like Gornja Trepča and Prolom for peaceful surrounding. There are a couple of dozen spas in Serbia that can be included in tourist offer. Good medical care, food and drink, manifestations, possibility of excursions are some of advantages that spas in Serbia possess.

Old railways tours provides traveling and siteseeing from past times. Šarganska osmica and trip to Sremski Karlovci are two of several tours whit old fashioned trains that tourist can take in Serbia. Tour includes traveling with steam locomotive and wooden wagons trough wild landscapes and organic food meals.

Holly places in Serbia are also notable tourist destinations that can be designed into very interesting tours for tourists. Several groups of monastery are called Serbian Athos. In Ibar valley nearly ten monasterys are located near to each other. Monasterys on Fruška gora are of great significance for Serbian history. Some of the monasterys are on UNESCO world heritage list. There are also traces of pagan temples, roman and greek holly places, early Christian basilicas, islamic and jewich temples and many others. In ortodox monastery tours with meals and wine tasting are available.

Cultural tourism is mostly underestimated part of Serbian offer which will be much more noticeable whit proper advertisement. Museums, galleries, legacies, memorial collections can be found in every part of Serbia. Tombstones called Stećci and krajputasi are specificity of Serbian burial traditions. There is also great variety of intangible heritage that can be interesting for foreign tourists. Cultural manifestations dedicated to music, poetry, history among others, can provide memorable tours for tourists all year long.

Salaš tours can become distinctive trademark of Serbian tourism, whit full-filed day programs including both rural and urban experiences. They represent unique life style from past ages. For tourist it would be an opportunity to experience way of life from past ages. Accommodation, 
service, food and drinks, music, every aspect of tourist offer made in a hundred or more year old fashion. Most salaš are located in Vojvodina, so the offer can be combined whit other parts of Vojvodina tourism. Combined they can bring new possibility for breakthrough of Vojvodina tourism. Visiting heritage sites, wineries, traditional manifestations, local food and beverage manufactures, riding horse sleigh and carriages, visiting kennels along with evenings at chardas are only some of the possibilitys that Salaš tours provide.

Visiting villages provides insight in way of life in Serbian rural environment. Whit number of ethno houses and villages that already have established themselves among tourists and just a little more diversification in their offer, this will become one of star products of Serbia tourist offer.

Fishing tourism is recovering after several decades of stagnation, but whit revitalization of fishing facilities and better control, this part of Serbian tourism can prove itself profitable. Fishing can be participated on rivers, lakes and other stagnant water, but also on channels and artificial lakes. Tourist can choose between couple of dozens fishing spots in all parts of Serbia, such as Danube, Sava, Morava, smaller rivers are mainly restocked too that can fish on Silver lake, Palić, or choose some of the channel spots for sport fishing. Fishing for catfish can represent top offer for tourists.

Hunting tourism can be respectable part of tourism industry, but there has to be more investments in hunting-grounds. Serbia hunting-grounds can offer game, quarry and fowling hunting. Because of the fact that hunting-grounds in Serbia were neglected in past twenty of thirty years there aren't much of trophy prey, but state in improving. Hunt on wild boar is most representing in Serbia. Some of the famous hunting-grounds in Serbia are Mali Jastrebac, Sokolovica, Vratna, Rit, Plavna and Karadjordjevo.

Agritourism is already very popular among tourists in Serbia because there are many ethnic households that provide tourists whit possibility of inclusion in farm life. Tourist can learn to make winter stories, jams, dairy products, juices, or even go on to collect mushrooms and herbs. They can also learn recipes for Serbian traditional dishes.
Whit significant number of wild rivers, canyons, peaks Serbia can be very attractive for extreme tourism. Conquest of unexplored canyons is popular amongst younger population and Serbia has couple of dozen canyons that fits this description. Canyons such as Jerma, Lazarev, Tribuće, Zvijezda and Dubrasnica are some of the most extreme in Europe, whit numerous waterfalls, caves and rapids, impassable whit out hiking equipment represent a challenge for every extreme sport lover. Rapids on river lbar are the best kayak on wild water track in Europe. There are also several other tracks on smaller rivers. Several walking tracks trough wild nature are marked providing not only site-seeing but also visiting remote villages of Serbia. Mountains are numerous in Serbia and some of them have peaks that will represent a challenge for every mountaineer.

Winter tourism, with only a couple of winter centers, in not yet very well developed, but with careful guidance, it will become respectful part of tourism in Serbia. Kopaonik and Zlatibor are well known in this region of the world, while Stara Planina, Tara and Divčibare are known mainly to domestic tourists. Plateau of Pešter can be used for winter walking and sledge rides. There is also a ski center Bjelasica on Šar panina, but because of the current political situation, it is unusable. There are many problems of winter tourism in Serbia, connection with cities, accommodation, number and quality of ski tracks, unmarked walk paths, to mention some. Serbia winter centers are better known by their night life rather than winter facilities. Serbian winter resorts are no match to Austrian or Suisse centers but with right planning, it can find place on world map of winter destinations. Plateau of Pešter can be used for winter walking and sledge rides.

There are also several other niches in Serbian tourist offer, such as canyoning, speleology tours, bird watching and others that can be taken in consideration. Also, in Serbia exists people whit new ideas for tourist offer in this part of the world, like dogsled tours and truffle finding tours. Offer exists, but it must be planned in order to support Serbia effort to regain her place on tourist map of today. 


\section{PROBLEMS OF TOURISM IN SERBIA}

Tourism in Serbia faces many problems, but main ones are segmentation, because tourist offer is segmented but it is not very well classified, Serbian tourism lacks global recognition, Serbia isn't on the top places in tourism statistic, and the biggest problem is state support.

Serbia is not recognized as relevant partner from big world operators such as TUI Travel and Thomas Cook group. These companies work whit agencies, hotels and other tourist facilities around the world giving services to millions of tourists, earning billions of dollars. If Serbia succeeds to cooperate whit one or several of global tour operators, and manages to put her offer in theirs catalogs, tourism in Serbia will have much more chances to revitalize.

Lack of infrastructure is possibly the biggest problem, because great investments are necessary to improve the state in Serbian infrastructure. Railways, regional, state and local roads, as well as air and river ports needs to be build or reconstructed. Highway in Serbia is yet to be built. Existing highway is bead, unsafe, poorly marked, badly directed, doesn't have sufficient auxiliary units, signalization is inadequate and gas stations and resting spots are few and wrongly distributed. Railways are in worst shape of all infrastructural facilities in Serbia. Railway roads are absolute, trains old, service beyond every level, delays are enormous and growing and station ruined. If railways don't get large investments in near future, tourists will have to find another way to get to Serbia. River ports are mainly industrial, even so there only few. Only one that receives cruise ships in Belgrade port. Other river cities in Serbia are invisible for tourist cruisers. Knowing that Serbia has several hundred waterways, this is discouraging fact. Novi Sad, Smederevo, Niš, Kladovo, Šabac, even Zemun doesn't have proper docking for tourist ships, and the one in Belgrade was built for different porpoise all together. Airports are in best shape of all infrastructure facilities in the country, but far from ideal. Airport in Belgrade in rather confusing and level of service is very bad, utility rooms are insufficient and taxi service is expensive and under average. Niš airport is not fully developed yet. Airports for sport flights are few and badly connected with main roads. There should be minor airports for purposes of private flights and taxi services. In this purpose some of former military airfields can be rebuilt.

Tourist facilities are insufficient, under average, and overcome. Many hotels don't fulfill modern standards, number of hostels must be bigger, and it seems as large percent of them is not connected whit tourist association in Serbia or in the world. Most of hotels in Serbia are couple of decades old, they lack to fulfill modern demand, their number is problematic, and their level of services must be improved. Hotels with five stars and resorts aren't many and there are located mainly in Belgrade and winter centers. Categorization of hotels in Serbia is problematic and their connection whit tourist organization appears to be bad. Hostels are better situated but they luck in number. Other facilities are mainly invisible for tourists from other countries.

Profile of people working in tourist and utility sector in Serbia is also problematic. For many of them this is only temporary job and their not trained for customer service. Structure of tourist agencies operating in Serbia is unsatisfactory, there offer is obsolete and undiversified. Agencies are not connected with global tour operators. They don't have diversified offer for local events or tours. Most of the staff in utility services speaks one or none foreign language. City tourist organizations are not visible in a way that tourist industry requires.

There are many stereotypes about Serbia, thanks to recent political events, war, instability of Serbian region, human rights threatening, social and economy problems, that make Serbia less desirable tourist destination.

\section{POSSIBLE SOLUTIONS}

Tourist offer of Serbia is presented badly in mass media. There should be commercials in length of fifteen and thirty seconds and one minute, whit top tourist offer from Serbia on carefully selected programs. Top television channels don't have any commercial concerning Serbian tourism. Specialized channels such as Travel channel don't broadcast commercials and travelogues about Serbia. Concerning the fact that Serbia is well-known by athletes, maybe sport channels 
such as Eurosport or even ESPN would be a spot to start campaign. Advertisement should contain well known places and events from Serbia that some of the viewers are already familiar with. Sites about Serbian tourist offer are interminable, often confusing, rarely updated and not very custom-caring. There are easy enough to find but it isn't very easy to find the needed offer on them. There aren't many banners and pop-ups with Serbian tourist offer on other sites concerning Serbia. In the time of social networks it is defeating to see the state of Serbian tourist presence on them.

There aren't any stands on main arrival places in Serbia. On airports there should be leaflets on the way out of the plains and around customs area, on railway and buss stations also. Festivals and traditional manifestation visited from tourists should advertise Serbian tourist offer as well.

Tourist organizations in cities should be more visible, they should approach tourists instead of waiting on them to find them. They have to have more diversified offer, more up to standard stands and objects put on center spots in the city.
Hotels are invisible on global market, they are not connected with global operators, top booking sites, and they don't seem to have solo booking offer for tourists. Tourist agencies, on other hand, are concentrated on domestic tourism.

\section{CONCLUSIONS}

Serbia confronts many obstacles in her effort to become recognizable tourist destination. Problems are many, but solvable. Image of the country needs to be improved. Investment in infrastructure and tourist facilities must be made, because it is the foundation whit out which the goal of making Serbia a developed tourist country is elusive. Segmentation of Serbian tourist offer, in accordance whit modern tourist demand, is also needed. In order to achieve these goals, every relevant part of Serbian tourist industry needs to take part in process of reinventing of Serbian tourism. Finding right vision, and making sustainable strategy, will enable Serbia to, developing correct marketing plan, make her mark on world tourist map.

\section{WORKS CITED}

Bakić, O. (2005). Marketing u turizmu. Beograd: Univerzitet Singidunum.

Biederman. P.S. (2008) Travel and Tourism: An Industry Prime. Upper Saddle River: N.J. Pearson Prentice Hall.

Ceranić, S. (2003). Strategijski menadžmnet. Beograd: Fakultet za menadžment malih i srednjih preduzeća.

Cooper, C., Fletcher, J., Fyall, A., Gilbert, D., \& Wanhill, S. (2008). Tourism Principles and Practise. Harlow: Pearson Education Limited.

Lopez-Guzman, T., Sanches-Canizares, S., \& Pavon, V. (2011) Community-based tourism in developing countries, $A$ case study. Rhodes: Tourismos: An International Multidisciplinary Journal of Tourism (6/1), University of the Aegean (pg. 69-84).

Matijašević, N. (2009). Measures for support to tourism development along the Danube river, Beograd: Regional cooperation in tourism development, Belgrade Chamber of Commerce (pg. 27-33).

Popesku, J. (2011). Menadžment turističke destinacije. Beograd: Univerzitet Singidunum.

Službeni glasnik Republike Srbije. (2006) Strategija razvoja turizma Republike Srbije. Beograd: Javno preduzeće Službeni glasnik (pg. 91)

Štetić, S. \& Šimičević, D. (2008). How to develop sustainiable tourism in rural destinations in Serbia, Beograd: Glasnik Srpskog geografskog društva, 88(4), Srpsko geografsko društvo (pg. 19-28).

Y. Gee, C. \& Fayos-Sola, E. (1997). International Tourism: A Global Perspective, Madrid: World Tourism Organization (UNWTO). 
Zrilić, D. (2011). Strategic Directions in Development of Rural Tourism in Serbia. Beograd: Regional cooperation in Tourism Development, Belgrade Chamber of Commerce (pg. 69-76).

Živković, R. (2007). Ponašanje i zaštita potrošača. Beograd: Univerzitet Singidunum.

Received for publication: $\quad$ 09.06.2014

Accepted for publication: $\quad$ 24.12.2014

\section{How to cite this article?}

Style - APA Sixth Edition:

Matković, M. (2015, Jan 15). Problems of tourism development in the Republic of Serbia. (Z. Čekerevac, Ed.) MEST Journal, 3(1), 177-184. doi:10.12709/mest.03.03.01.19

Style - Chicago Fifteenth Edition:

Matković, Milutin. 2015. "Problems of tourism development in the Republic of Serbia." Edited by Zoran Čekerevac. MEST Journal (MESTE) 3 (1): 177-184. doi:10.12709/mest.03.03.01.19.

Style - GOST Name Sort:

Matković Milutin Problems of tourism development in the Republic of Serbia [Journal] // MEST Journal / ed. Čekerevac Zoran. - Belgrade : MESTE, Jan 15, 2015. - 1 : Vol. 3. - pp. 177-184.

Style - Harvard Anglia:

Matković, M., 2015. Problems of tourism development in the Republic of Serbia. MEST Journal, 15 Jan, 3(1), pp. 177-184.

Style - ISO 690 Numerical Reference:

Problems of tourism development in the Republic of Serbia. Matković, Milutin. [ed.] Zoran Čekerevac. 1, Belgrade : MESTE, Jan 15, 2015, MEST Journal, Vol. 3, pp. 177-184. 